\title{
Proximate Analysis and Determination of Some Selected Vitamins and Minerals Contents of Terminalia Catappa Endocarp Flour
}

\author{
Philemon C Anuforo ${ }^{1 *}$, Ngozi K Achi ${ }^{1}$, Anthony Cemaluk C Egbuonu ${ }^{1}$ and Elizabeth U Egu ${ }^{2}$ \\ ${ }^{1}$ Department of Biochemistry, Michael Okpara University of Agriculture, Umudike, Umuahia Abia State, Nigeria \\ ${ }^{2}$ Department of Nutrition and Dietetics, Michael Okpara University of Agriculture, Umudike, Umuahia Abia State, Nigeria
}

Received: August 18, 2017; Accepted: September 04, 2017; Published: October 24, 2017

*Corresponding author: Philemon C Anuforo, Department of Biochemistry, Michael Okpara University of Agriculture Umudike, Abia State, Nigeria, Tel: +23480-3526-0857; E-mail: philanfo@yahoo.com

\begin{abstract}
This study was designed to determine the proximate, minerals, vitamins content of milled Terminalia catappa endocarp flour as possible source of nutrients. The analyses were done using standard methods of Association of Official Analytical Chemists (AOAC). The result of the proximate composition showed the following; moisture $(5.00 \pm 0.28 \mathrm{~g} / 100 \mathrm{~g})$, ash content $(11.03 \pm 0.25 \mathrm{~g} / 100 \mathrm{~g})$, crude protein $(8.28 \pm 0.35 \mathrm{~g} / 100 \mathrm{~g})$, crude fat $(8.53 \pm 0.18 \mathrm{~g} / 100 \mathrm{~g})$, crude fibre $(36.33$ $\pm 0.18 \mathrm{~g} / 100 \mathrm{~g})$ and carbohydrate $(30.85 \pm 0.71 \mathrm{~g} / 100 \mathrm{~g})$. The mineral contents;calcium $(220.19 \pm 0.19 \mathrm{mg} / 100 \mathrm{~g})$, magnesium (43.66 \pm 0.06 $\mathrm{mg} / 100 \mathrm{~g})$, phosphorus $(41.87 \pm 0.99 \mathrm{mg} / 100 \mathrm{~g})$, potassium $(326.32$ $\pm 0.18 \mathrm{mg} / 100 \mathrm{~g})$, sodium $(16.75 \pm 0.13 \mathrm{mg} / 100 \mathrm{~g})$. It also contained vitamin A $(6.45 \pm 0.00 \mathrm{mg} / 100 \mathrm{~g})$, vitamin $\mathrm{B} 2$ - riboflavin $(0.09 \pm 0.01$ $\mathrm{mg} / 100 \mathrm{~g})$, vitamin $\mathrm{B} 1$ - thiamine $(0.345 \pm 0.10 \mathrm{mg} / 100 \mathrm{~g})$, vitamin B3 - niacin $(2.52 \pm 0.09 \mathrm{mg} / 100 \mathrm{~g})$ and vitamin C - ascorbic acid $(14.58 \pm 0.09 \mathrm{mg} / 100 \mathrm{~g})$. Terminalia catappa wastes can be sources of nutrients, mineral elements and vital vitamins that were nutritionally important for body health. Therefore, proper exploration of these waste will result in proper tropical almond wastes utilization and help in solid waste management (waste reduction), thereby resulting environmental sustainability.
\end{abstract}

Keywords: Terminalia catappa; Proximate Analysis; Mineral Content

\section{Introduction}

Terminalia catappa is a large tropical tree in the family combretaceae that is native to the tropical regions of Asia, Africa and Australia, known for its nutritional fruit and possession of medicinal benefits. It is a tall, semi-deciduous, erect, medium to large sized tree 10 to $25 \mathrm{~m}$ tall. It is found in almost all the regions of the country as it thrives well in the tropics, hence its name tropical almond. It has a single stem which grows to a height of about $10 \mathrm{~m}$ and then branches horizontally with leaves at the end of the branches that form a rosette [1, 2]. The fruit is a sessile, laterally compressed, oval-shaped drupe. This drupe is 2.5 inches long and mature from green to yellow or red during the summer.
The outside husk is corky fiber with an inner thin green flesh. The inside holds the edible, almond-like kernel [3]. Fruit colour changes from green in young to dark purplish red at full maturity. Rind of the fruit is light, pithy or corky tissue and float in the sea and thus dispersed by ocean currents. Each fruit contains a creamcoloured seed, which encloses the kernel (nut). The fruit endocarp (pod) which is considered to be of little or no significance is often discarded as waste after the fruit is being harvested, thereby constituting a menace to the environment. It is a contributor of municipal waste [4]. However, studies have revealed that they are good sources of important nutrients, supplying the body with minerals salts, vitamins and certain hormone precursors, protein, energy and essential amino acid [5, 6]. The leaves and fruit of Terminalia catappa are astringent. The leaves act as a vermifuge (especially the red leaves), serve as analgesic, as well as, used to treat yaws while the kernel of the fruit when mixed with beeswax stops putrid exudation and bloody faeces [7]. The bark and root bark are useful for bilious fever, diarrhoea, thrush, remedy for sores and abscesses and recommended as a mild laxative and a galactagogue for women, but too frequent use causes diarrhea [7]. The flesh and kernel of the fruits are eaten raw, sun dried or roasted. The leaves, roots and bark are however used for treating diseases such as anemia, hypertension, malaria, fever and asthma, the leaves have been shown to protect against acute liver injury produced by some hepato-toxicants [8]. The kernel can be eaten raw or roasted and has an almond-like taste. Sun-dried kernels yield $34-54 \%$ of bland, yellow, semi-drying oil that is edible but becomes turbid on standing [9]. The oil is mainly used in cooking. The flesh of the fruit is also edible but is often fibrous and not very tasty in spite of the pleasant smell. The kernel is also rich in lipids; a viable source of extractable edible oil used for cooking while the foliage is used as a feed for silkworms and other animal feed and provides a source for timber, gum or resin and tannin or dyestuff [7]. The major aim of this study seeks to investigate the nutritional value of Terminalia catappa endocarp flour. 


\section{Materials and Methods}

\section{Plant materials and authentication}

Fruits of Terminalia catappa were harvested from College of Pure and Applied Sciences (COLPAS) of Michael Okpara University of Agriculture, Umudike, Abia State, Nigeria, during the morning hours between $1^{\text {st }}$ and $4^{\text {th }}$ week of June, 2015. The plant was identified and authenticated by Mr. K. Ibe of Forestry and Environmental Management, College of Natural Resources and Environmental Management, Michael Okpara University of Agriculture, Umudike, Abia State, Nigeria.

\section{Preparation of plant materials}

The fresh fruits of Terminalia catappa were washed, peeled (to remove the edible ectocarp), air dried at a temperature of $35^{\circ} \mathrm{C}$ (to remove excess moisture), deshelled and the resultant shell (endocarp) milled. The ethanol extract of endocarp flour was prepared by soaking $250 \mathrm{~g}$ of Terminalia catappa flour in 1 litre of ethanol for 72 hours at room temperature with vigorous shaking. The mixture was filtered with Whatman filter paper No.1. The filtrate was then dried at a temperature of about $40^{\circ} \mathrm{C}$ in oven and stored in refrigerator in a capped beaker at $4^{\circ} \mathrm{C}$ for further use and percentage yield was calculated using:

Percentage yield $=\frac{W_{2}-W_{1}}{W_{2}} \times 100$

Where; $\mathrm{W}_{2}=$ Weight of semi-solid aqueous extract

$\mathrm{W}_{1}=$ Weight of the Terminalia catappa flour before extraction

\section{Determination of proximate composition of Terminalia catappa}

The Association of Official Analytical Chemist procedure was used to determine the proximate compositions [10].

\section{Determination of some vitamins}

Determination of some of the vitamins contents were carried out according to the method described by while ascorbic acid was determined by the method described by $[11,12]$.

\section{Determination of some minerals}

The mineral content of the sample was determined by the dry ash acid extraction method described by [12]. A measured weight of the sample (2g) was burnt to ashes (as in ash determination) in a muffle furnace at $550^{\circ} \mathrm{C}$. The resulting ash was dissolved in $10 \mathrm{mLs}$ of $2 \mathrm{M} \mathrm{HCl}$ solution and diluted to $90 \mathrm{~mL}$ of distilled water in a volumetric flask and filtered. The filtrate was used on the mineral analysis.

\section{Results}

Proximate composition of Terminalia catappa endocarp flour

Results of the proximate compositions of the Terminalia catappa endocarp (pod) are presented in (Table 1). As shown in Table I, the highest proximate content was crude fibre $(36.33$ $\pm 0.18 \mathrm{~g} / 100 \mathrm{~g})$, followed by carbohydrate $(30.85 \pm 0.71 \mathrm{~g} / 100 \mathrm{~g})$ while the least was moisture $(5.00 \pm 0.28 \mathrm{~g} / 100 \mathrm{~g})$ followed by crude protein $(8.28 \pm 0.35 \mathrm{~g} / 100 \mathrm{~g})$.

Table1: Proximate composition of Terminalia catappa endocarp flour

\begin{tabular}{|c|c|}
\hline Parameter & Concentration (g/100g) \\
\hline Moisture Content & $5.00 \pm 0.28$ \\
\hline Ash Content & $11.03 \pm 0.25$ \\
\hline Crude Fiber & $36.33 \pm 0.18$ \\
\hline Crude Fat & $8.53 \pm 0.18$ \\
\hline Crude Protein & $8.28 \pm 0.35$ \\
\hline Carbohydrate & $30.85 \pm 0.71$ \\
\hline
\end{tabular}

Values are means \pm standard deviations of triplicate determinations

\section{Vitamin compositions of Terminalia catappa endocarp flour}

Results of the vitamins compositions of Terminalia catappa endocarp flour are presented in (Table 2). As shown in Table 2 , the highest vitamin composition was ascorbic acid (14.58 \pm $0.09 \mathrm{mg} / 100 \mathrm{~g})$ followed by retinol $(6.45 \pm 0.00 \mathrm{mg} / 100 \mathrm{~g})$ while the least was riboflavin $(0.09 \pm 0.01 \mathrm{mg} / 100 \mathrm{~g})$.

Table 2: Vitamin compositions of Terminalia catappa endocarp flour

\begin{tabular}{|c|c|}
\hline Vitamin & Concentration (mg/100g) \\
\hline Thiamine $\left(\mathrm{B}_{1}\right)$ & $0.345 \pm 0.10$ \\
\hline Riboflavin $\left(\mathrm{B}_{2}\right)$ & $0.09 \pm 0.01$ \\
\hline Niacin $\left(\mathrm{B}_{3}\right)$ & $2.52 \pm 0.09$ \\
\hline Retinol $(\mathrm{A})$ & $6.45 \pm 0.00$ \\
\hline Ascorbic Acid (C) & $14.58 \pm 0.09$ \\
\hline $\begin{array}{l}\text { Values are means } \\
\text { determinations }\end{array}$ & standard deviations of triplicate \\
\hline
\end{tabular}

\section{Mineral compositions of Terminalia catappa endocarp} flour

The Terminalia catappa endocarp flour contain relatively high amount of important mineral (Table 3). Results showed that the potassium concentration $(336.32 \pm 0.18 \mathrm{mg} / 100 \mathrm{~g})$ was the highest, followed in descending order by calcium $(220.19 \pm$ $0.19 \mathrm{mg} / 100 \mathrm{~g})$, magnesium $(43.66 \pm 0.06 \mathrm{mg} / 100 \mathrm{~g})$, phosphorus (41.87 $\pm 0.99 \mathrm{mg} / 100 \mathrm{~g})$ and sodium $(16.75 \pm 0.13 \mathrm{mg} / 100 \mathrm{~g})$. 


\begin{tabular}{|c|c|}
\hline Table 3: Mineral composition of & Terminalia catappa endocarp flour \\
\hline Mineral Compositions & Concentration (mg/100g) \\
\hline Calcium & $220.19 \pm 0.19$ \\
\hline Magnesium & $43.66 \pm 0.06$ \\
\hline Sodium & $16.75 \pm 0.13$ \\
\hline Potassium & $326.32 \pm 0.18$ \\
\hline Phosphorus & $41.87 \pm 0.99$ \\
\hline
\end{tabular}

Values are means \pm standard deviations of triplicate determinations

\section{Discussion}

\section{Proximate composition}

From the result, the endocarp flour had high carbohydrate content which was higher compared to the values reported for Terminalia catappa leaves implying that almond endocarp flour could serve as a good source for carbohydrate [13,14]. Carbohydrates are easily digested and provide the necessary calories in the diets of humans.

The crude fiber content reported for almond endocarp in this study was very high compared to those reported for Terminalia catappa, suggesting that Terminalia catappa endocarp could serve as a good dietary fiber source $[15,13]$. Dietary fiber can lower cholesterol level, risk of coronary disease, hypertension, constipation, diabetes, colon and breast cancer [16]. Fiber improves food bulk, appetite satisfaction and the movement of food through the digestive system, as well as, prevents constipation $[17,18]$.The consumption of diets rich in plant foods (and therefore fiber) is inversely related to the incidence of cardiovascular disease, colon cancer, and diabetes. One plausible mechanism for an anti carcinogenic effect is the rapid passage of the digestive mass through the colon, thereby reducing the possibility that potential carcinogens have an opportunity to interact with the mucosal surface [19].

The moisture content was very low compared to $31.05 \pm$ 0.04 obtained for the red variety kernel as reported by Oduro et al. This low moisture content of Terminalia catappa endocarp could increase its storage time. Generally, high moisture content enhances the growth of microorganisms and hence microbial spoilage of food. The moisture content reported in the present study for Terminalia catappa endocarp flour was similar compared to $5.5 \%$ and $5.1 \%$ for cashew nut and african oil bean respectively $[20,21]$.

The ash content of Terminalia catappa endocarp flour was high compared to $5 \%$ reported for Terminalia catappa seed and $2.76 \pm 0.11 \%$ reported for the red variety seed of Terminalia catappa $[22,13]$. Ash content signifies the level of mineral present in the sample.

The crude protein content of Terminalia catappa endocarp flour was low compared to $36.69 \%$ reported for Terminalia catappa seed, but higher than $0.65 \%$ reported for Terminalia catappa nut $[13,23]$.However, $23.78 \pm 0.15 \%$ was reported for the same Terminalia catappa seeds/nut [22]. The $8.23 \pm 0.35 \mathrm{~g} / 100 \mathrm{~g}$ reported for crude protein represents $24.43 \%$ of the dietary allowance for protein for a $70 \mathrm{~kg}$ man [19]. Protein could be used as a dietary supplement for people who need a lot of protein, and most importantly for those who require plant protein e.g. people suffering from hypertension. It can also be incorporated into animal feed to increase the protein content.

\section{Minerals and vitamins compositions}

The potassium concentration in almond endocarp was high compared to $350.00 \mathrm{mg} / 100 \mathrm{~g}$ reported for Terminalia catappa [13]. The dietary allowance for potassium is $2000 \mathrm{mg}$ for adults [19].

The Terminalia catappa flour potassium content was 336.32 $\pm 0.18 \mathrm{mg} / 100 \mathrm{~g}$ which contributed about $17.0 \%$ of the RDA. Therefore, Terminalia catappa flour could be recommended as source of dietary supplement for potassium. Potassium is an essential nutrient and has an important role in the synthesis of amino acids and proteins [24].

Calcium content in almond flour was $220.19 \pm 0.19 \mathrm{mg} / 100 \mathrm{~g}$. This value is high when compared to $36.1 \mathrm{mg} / 100 \mathrm{~g}$ obtained for Terminalia catappa, but low when compared to $827.20 \pm$ $2.18 \mathrm{mg} / 100 \mathrm{~g}$ reported for Terminalia catappa nut $[13,15]$. The magnesium content was $43.66 \pm 0.06 \mathrm{mg} / 100 \mathrm{~g}$ in the endocarp flour. This value was low compared to $798.60 \pm 0.32 \mathrm{mg} / 100 \mathrm{~g}$ reported for almond nut [15]. Calcium and magnesium play a significant role in photosynthesis, carbohydrate metabolism, nucleic acids and binding agents of cell walls [25]. Calcium assists in teeth and bone development [26]. However, its presence in high concentration may be a risk factor for hypertensive patients since it results in calcification of the arteriole walls. Magnesium is an essential mineral for enzyme activity. Like calcium and chloride, magnesium also plays role in regulating the acid-alkaline balance in the body. High magnesium levels in drinking water have been linked to resistance to heart disease [27].

The phosphorus content of Terminalia catappa $(41.87 \pm 0.99 \mathrm{mg} / 100 \mathrm{~g})$ obtained for almond endocarp flour was higher compared to $10.00 \mathrm{mg} / 100 \mathrm{~g}$ obtained for Terminalia catappa [13]. However, was low when compared to $4000 \mathrm{mg} / 100 \mathrm{~g}$ obtained for Benin seeds [28]. The dietary allowance for phosphorous was $800 \mathrm{mg} / 100 \mathrm{~g}$, hence, $41.87 \pm 0.99 \mathrm{mg} / 100 \mathrm{~g}$ contributed about $5.23 \%$ of the RDA, implying that Terminalia catappa endocarp flour could not serve as a rich source of phosphorus as supplements [19].

The vitamin $\mathrm{A}$ and $\mathrm{C}$ content are adequate to supplement other dietary sources. Vitamin A is a good treatment for people suffering from eye problem while deficiency of vitamin $C$ leads to scurvy and gingivitis. The vitamin $\mathrm{A}$ and $\mathrm{C}$ concentrations obtained for Terminalia catappa endocarp were high compared to the $0.710 \mu \mathrm{g} / \mathrm{g}$ and $0.030 \mu \mathrm{g} / \mathrm{g}$ reported respectively [23]. 


\section{Conclusion}

The proximate, mineral and vitamin screening of Terminalia catappa endocarp revealed that it can be good sources of nutrients, mineral elements and vital vitamins that were nutritionally important for body health. Although, the endocarp of Terminalia catappa is often regarded as waste, nutritionally, they compare favorably with most popularly consumed vegetables based on their moisture content, ash content, crude lipid, crude fiber, crude protein and carbohydrate. Therefore, proper exploration of these wastes will result in wastes utilization thereby resulting environmental sustainability.

\section{References}

1. Arbounier M. Trees, shrubs and lianas of West Africa dry zones, Margraf Publishers, Great Britain, 2002;273.

2. Thomson LAJ, Evans B. Terminalia catappa (tropical almond), ver.2.2. In: Elevitch, C.R. (Ed.). Species profiles for pacific island agroforestry. Permanent agriculture resources (PAR), Hōlualoa, Hawaii.

3. Fox AM, Gordon DR, Dusky JA, Tyson L, Stocker RK. IFAS assessment of non-native plants in Florida's natural areas: Status assessment.

4. Gui-Fang Deng, Chen Shen, Xiang-Rong Xu, Ru-Dan Kuang, Ya-Jun Guo, Li-Shan Zeng, et al. Potential of fruit wastes as natural resources of bioactive compounds. Int J Mol Sci. 2012;13(7): 8308-8323. doi: 10.3390/ijms13078308

5. Marcel A, Bievenu MJ. Proximate, Mineral and Phytochemical Analysis of the Leaves of H. myriantha and Urera trinervis. Pak J Biol Sci. 2012;15(11): 536-541.

6. Amaechi NC. Nutritive and anti-nutritive evaluation of wonderful kola (Buccholzia coricea) seeds. Pakistan J Nutri. 2009;8:1120-1122.

7. Orwa C, Mutua A, Kindt R, Jamnadass R, Anthony S. Agroforestree Database: A tree reference and selection guide version 4.0.

8. Mudi SY, Muhammad A. Phytochemical screening and antimicrobial activities of Terminalia catappa, Leaf Extracts. Biokemistri. 2011;23(1):35-39.

9. Dukes. Phytochemical and ethnobotanical database.2008;11.

10. Association of Official Analytical Chemists. Official methods of analysis.15th ed. Washington, DC:1990.

11. Association of Official Analytical Chemists. Official Methods of Analysis of AOAC International (17th ed). Gaithersburg, Md. 2002.

12. James CS. Analytical chemistry of foods. Chapman and Hall,/ New York.

13. Akpabio UD. Evaluation of proximate composition, mineral element and anti- nutrient in almond (Terminalia catappa) seeds. Adv Appl Sci Res. 2012;3(4):2247-2252.
14. Oluwole OS, Makinde SCO, Yusuf AK, Fajana OO, Odunmosu OA. Determination of heavy metal contaminations in leafy vegetables cultivated by the road side. Int J Eng Res and Technol. 2013;7(3): 01-05.

15. Matos L, Ndangui CB, Nzikou JM, Kimbonguila A, Pambou-Tobi NPG, Abena T, et.al. Composition and nutritional properties of seeds and oil from Terminalia catappa. Adv J Food Sci and Technol. 2009;1(1):72-77.

16. Rao CV, Newmark HL. Chemopreventive effect of squalene on colon cancer. Carcinogenesis. 1998;19(2):287-290.

17. Edem, Christopher A. Dosunmu, Miranda I, Bassey Francesca I. Determination of proximate composition, ascorbic acid and heavy metal content of African walnut (Tetracarpidium conophorum). Pakistan J Nutri. 2009;8(3): 225-226. DOI:10.3923/ pjn.2009.225.226

18. Erhirhie EO, Ekene NE. Medicinal values on Citrullus lanatus (Watermelon): Pharmacological review. Int J Res Pharm and Biomed Sci. 2013;4:1305-1332.

19. National Research Council. Food and nutrition board. Recommended dietary allowance (8th ed.). National Academy of Science, 1989;2032.

20. Fetuga BL, Batunde GM, Oyenuga UA. Protein quality of some Nigerian feed crops (1st ed.). Racine Publishing Co. Ibadan,1974;58-65.

21. Osagie AU, Okoye WI, Oluwayose BO, Dawodu DA. Chemical quality parameters and fatty acid composition of oils of some underexploited tropical seeds. Nig J Appl Sci. 1986;4(2):151-162.

22. Oduro I, Larbie C, Amoako TNE, Antwi-Boasiako AF. Proximate composition and basic phytochemical assessment of two common varieties of Terminalia catappa (Indian almond). J Sci and Technol. 2009;29(2):1-11.

23. Agatemor C, Mark E. Nutritional Potential of the Nut of Tropical Almond (Terminalia catappa L.). Pakistan J Nutri. 2006;5(4):334336.

24. Malik CP, Srivastava AK. Text book of plant physiology. New Delhi:Ludhiana. 1982.

25. Russel EW. Soil conditions and plant growth. Supergene Zone, M. Nedra, 19 (in Russian).1973.

26. Brody T. Nutritional biochemistry. San Diego, CA: Academic Press;1994;761-794.

27. Fallon S, Enig MG. Nourishing traditions: The cookbook that challenges policitally correct nutrition and the diet dictocrats. 2001;40-45.

28. Dashak DA, Fali CN. Chemical composition of four varieties of Nigeria benniseed. Food Chemistry. 1993;47(3): 53-75. 